\title{
EDITORIAL
}

\section{Watching Canada's experiment with legal cannabis}

\author{
Diane Kelsall MD MEd
}

Cite as: CMAJ 2018 October 15;190:E1218. doi: 10.1503/cmaj.181287

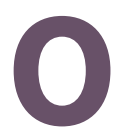

n Oct. 17, 2018, the government of Canada will launch a national, uncontrolled experiment in which the profits of cannabis producers and tax revenues are squarely pitched against the health of Canadians. When Bill C-45 comes into force in mid-October, access to recreational marijuana will be legal, ${ }^{1}$ making Canada one of a handful of countries to legalize recreational use of the drug. Given the known and unknown health hazards of cannabis, ${ }^{2,3}$ any increase in use of recreational cannabis after legalization, whether by adults or youth, should be viewed as a failure of this legislation. The government of Canada should commit to amending the act if cannabis use rises.

Predictably, given the federal government's stated commitment to pushing this legislation through, investment in cannabis firms has risen substantially over the past year in anticipation, and new producers, large and small, have been popping up across the country. Their goal is profit, and profit comes from sales - sales of a drug that, according to Health Canada, will cause a problem in nearly 1 in 3 adult users and an addiction in close to 1 in 10 , with higher risks in youth. ${ }^{2}$

We cannot expect cannabis firms to restrict their growth ambitions or to have use reduction as a goal. Cannabis companies may initially focus on attracting current consumers from black-market sources, but eventually, to maintain or increase profits, new markets will be developed as is consistent with the usual behaviour of a for-profit company. ${ }^{4}$ Marketing efforts may include encouraging current users to increase their use or enticing a younger demographic. The track record for tobacco producers has not been encouraging in this regard, and it is unlikely that cannabis producers will behave differently.

The provisions regarding promotion of cannabis were the subject of much debate as the bill wended its way through the legislative process. Although the act prohibits promotion to young people and marketing may not evoke a way of life that includes "glamour, recreation, excitement, vitality, risk or daring," among other restrictions, ${ }^{1}$ there is plenty of leeway for cannabis companies to attract users. Promoting brand preference and providing "informational" materials are allowed in places where young people are not permitted by law, for example. And the decision by the federal government to legalize cannabis sends a clear message to Canadians that its use is acceptable.

We are already seeing the rise of cannabis brands and can expect cannabis firms to promote their products to the full extent allowed under law - and possibly beyond. This past summer, cannabis companies were promoting their wares at music festivals and similar venues to ensure brand-awareness ahead of the legislation. ${ }^{5}$ Even the food and beverage industry is joining in with plans to augment their products with cannabis.
Bill C-45 explicitly states that its purpose is to protect public health and safety, by keeping cannabis out of the hands of youth and enhancing public awareness of health risks associated with cannabis use. ${ }^{1}$ To achieve this will require a concerted effort by government at all levels. Analyzing the experiences of other jurisdictions that have legalized recreational cannabis should prove helpful, ${ }^{4}$ as will thoughtful reflection on Canada's successes - or lack thereof - in tobacco and alcohol control.

Many local and provincial governments have put regulations in place to restrict the use and distribution of cannabis, beyond the broad provisions in the federal legislation. And health authorities are working on campaigns to raise awareness of health and other risks, such as impaired driving, associated with cannabis use.

But fundamentally, the federal government needs to take responsibility for the consequences of this controversial legislation. To that end, it must provide adequate funding for robust monitoring of cannabis use among all segments of society, especially among youth and other populations at particular risk. The anticipated windfall of tax revenue should fund research on harms related to use, as there are many unanswered questions about the short- and long-term implications of cannabis use. ${ }^{3}$ And finally, if use of cannabis increases, the federal government should have the courage to admit the legislation is flawed and amend the act. Canadians - and the world - will be watching.

\section{References}

1. An Act respecting cannabis and to amend the Controlled Drugs and Substances Act, the Criminal Code and other Acts. 42nd Parliament, 1st sess, 2018 June 21. Available: www.parl.ca/Content/Bills/421/Government/C-45/C-45_4/C-45_4.PDF (accessed 2018 Sept. 27).

2. What you need to know about cannabis. Ottawa: Health Canada; (modified 2018 Sept. 6). Available: www.canada.ca/en/services/health/campaigns/ cannabis/canadians.html\#a2 (accessed 2018 Sept. 27).

3. Memedovich KM, Dowsett LE, Spackman E, et al. The adverse health effects and harms related to marijuana use: an overview review. CMAJ Open 2018;6:E339-46.

4. Vogel L. What really happened after Colorado legalized marijuana? [news]. CMAJ 2018 Sept. 26. Available: https://cmajnews.com/2018/09/26/what-really-happened -after-colorado-legalized-marijuana-cmaj-109-5665/ (accessed 2018 Sept. 27).

5. Buckner D. Cannabis marketers enjoy summer of schmooze ahead of legislative crackdown. CBC News 2018 July 11. Available: www.cbc.ca/news/business/ cannabis-promotion-despite-coming-law-1.4740933 (accessed 2018 Sept. 27).

Competing interests: See www.cmaj.ca/site/misc/cmaj_staff.xhtml

Affiliation: Editor-in-Chief (interim), CMAJ

Correspondence to: CMAJ editor, cmaj@cmajgroup.ca 